\title{
Neo-Colonialism and alienation in African fiction: Ayi Kwei Armah's Fragments
}

\author{
Kwadwo Osei-Nyame, Jnr \\ Lecturer \\ African Literature(s), Language(s) Cultural and Diaspora Studies \\ Africa Department \\ School of Oriental and African Studies \\ University of London, London \\ E-mail: ko9@soas.ac.uk
}

Submitted: June 12, 2019 / Accepted: July 23, 2020 / Published: December 30, 2020

\begin{abstract}
This article examines the themes of neo-colonialism and alienation in Ayi Kwei Armah's novel Fragments. It contends that these are two of the most topical subjects within African existence in the contemporary era and are still very directly related to the present African predicament of a seemingly developmentally slow and retrogressing continent. Alienation and neocolonialism are also inextricably intertwined with the whole question of nation-building and nationalism and directly linked with issues relating to African identity in the aftermath of slavery and colonialism. The discussion suggests that Ayi Kwei Armah's engagement of the themes of neocolonialism, alienation, nationalism and nation-building offer some very useful insights into grappling with the present African condition. Ultimately, the point is made that examining and exploring the nature and intricacies of neo-colonialism and alienation of both individuals and community through the experiences of protagonists in the fiction discussed contributes to facilitating an understanding of the project of African self-rehabilitation and reclamation, which are pursued through nation-building and nationalism and which are currently ongoing.
\end{abstract}

Keywords: Colonialism, neo-colonialism, alienation, family, community, nationalism, decolonization, national consciousness, nationbuilding, culture, liberation

"I know what I'm expected to be... It's not what I want to be." Baako, Fragments (Armah, 1969, p. 147) 


\section{Introduction}

The epigraph that foregrounds this essay into the relationship between a novel published over fifty years ago and the present African moment is intricately tied to the illusory promise of independence and an awakening of ideological consciousness that sees the suggested path to a viable nationstate as one fraught with disappointment and danger, even as one hegemonic empire appears to have relinquished its hold on an erstwhile colony. Under such conditions of a false consciousness and materialist delusions, which were the hallmarks of the post-independence era, the examination of Ayi Kwei Armah's Fragments reveals that although externalities may have changed in the intervening decades, the underlying structural weaknesses suggested in Armah's choice of the novel title still persist today and make the inquiry all the more necessary.

This discussion is interested specifically in Armah's 1969 novel Fragments, whose narrative voice at the beginning is that of Naana, Baako's grandmother, who is observing and making philosophical statements that ultimately comment and reflect on the general state of affairs within the society. Naana's observations are cast mainly as a censure of the society and a critique of its decaying morals as exemplified in Baako's uncle Foli, who in pouring libation to the ancestors on Baako's behalf prior to his journey abroad, withholds some of the drink meant for the departed souls of the clan. ${ }^{1}$ Foli's sacrilegious actions within the context of long-held, age-old, culturally sacrosanct and cherished traditions can cause a rupture within the cosmic order of the community. Naana's early observations are meant therefore then as an ideological critique of the events that will unfold in the narrative.

Naana's mention of "a spirit flawed by the heaviness of flesh" (Armah, 1969, p. 5) in reference to the dishonest Foli is ultimately of wider significance in the novel's symbolic 1 Ode Ogede suggests that: "Naana's is the voice of the wise elder who has witnessed the ideal past that is threatened" and who "laments the erosion and distortion of African civilisation by an alien system of values and reveals her respect for the order under siege." (Ogede, 2000: 59)

Legon Journal of the Humanities 31.1 (2020)

Page $\mid 93$ 
narrative structure and within the wider scheme of unfolding events. Rosemary Colmer is correct in this regard in observing that thematically Armah develops "the dichotomy between the material world and spiritual one" (Colmer, 1992, p. 192). Naana is the one responsible for drawing attention to the essential nature of the relationship of humankind to the spiritual world. Consequently, she ensures that Foli appropriately appeases the ancestors:

I watched everything that night, and I am weak, but with the little strength that I still had in me I would myself had stopped the drunken Foli if he had gone wrong anywhere, adding things unknown to those gone before, or leaving out any of the words and actions they have left us to guide us on our circular way. (Armah, 1969, p. 4)

It is Naana's task and mission to ensure that the cycle of life remains in perfect order and unbroken. ${ }^{2}$

\section{Contested ideologies and identities}

Fragments establishes an ideological order in which the likes of Naana and Baako represent a desire for Africa's spiritual renaissance, while others like Foli and Brempong are representative of its moral decadence and adulation of the West. Consequently, for instance, while Baako and Brempong are both Western-educated been-to's, the narrative clearly demarcates them as representing different philosophical positions within the discourse of nation-building and nationalism. Brempong on his way home to Ghana is described as "exuding an irrepressible happiness" (Armah, 1969, p. 61), while throughout the narrative 2 Kirsten Holst Petersen suggests that Naana: "is firmly rooted in traditional African thinking which is essentially a religious mode of perception, rejecting rational, scientific explanation of phenomena in favour of a transcendental, mythical system which defies logic and operates through ritual." This is a presumptions position though. First, African ritual does not defy logic, while its putative religious mode of perception is neither irrational or unscientific. The further view that "traditional African thinking" is "essentially religious" has no rational basis at all and is reductionist, to say the least (Petersen, 1992: 218)

Legon Journal of the Humanities 31.1 (2020) 
Baako is presented as a man in a state of unease, who falls "very ill" (Armah, 1969, p. 51) before his return home and who, according to his mother Efua, "did not [even] want to come back home" (Armah, 1969, p. 50).

Baako's uncertainty and his aloofness have to do with the correlation between his own anxieties and apprehensions and the state of his country Ghana, where all is really not well. He admits on the flight home to Brempong to being "[a] little nervous." "I don't know what I'm going to find" (Armah, 1969, p. 65); a statement which judging by the alienation Baako experiences in Ghana upon his arrival confirms that he was right to be concerned. The exuberant Brempong on the other hand feels no sense of unease because he fits perfectly within the neocolonially minded and structured Ghanaian society. While the group of Western-educated Africans are presented as collectively responsible for Ghana's destiny, Baako is on opposing sides to Brempong, who is described as having "a smile like something learned from the advertisements for beer or whisky or cigarettes made specially for the new Africans" (Armah, 1969, p. 62; emphasis added). This suggests that he is part of an act, a role that he is to play, in a commercial drama written by someone else in which he is the vampiric consumer of his nation's own potential.

While the "new Africans" such as Baako and Brempong are potentially part of the nation-building project, particularly important is the question of what kind of ideological perspectives and intellectual positions inform their minds and character, and what exactly their contribution to the nationalist project is meant to be. When they introduce themselves to each other on the journey back home, Brempong's brashness, pomposity and boastfulness are in direct contrast to Baako's rather shy, humble and gentle nature:

"Brempong is my name, he said. "Henry Robert Hudson Brempong." 
"Baako" "Is that your Christian or your surname?" Brempong asked.

"No Christian name," said Baako. "I'm not a Christian." (Armah, 1969, p. 63)

Baako's statement to the effect that he is "not a Christian" already marks him as different from the majority of "new Africans" of whom Brempong is more prototypically representative. Baako's disavowal of Christianity -- and hence his potential Europeanness -- is clearly against the background of the fact that Brempong, who has thoroughly assimilated Western culture and luxuriates in it, seems confounded that Baako does not have a Christian name:

\footnotetext{
"You know," said Brempong, "you know, your other names." He chuckled, a bit uncertainly, at the end.

"Onipa"

"It's an unusual name," Brempong said.

"My family name," said Baako. "I think of it as very common name myself."

"Ah, yes," Brempong laughed. "I see what you mean, yes." (Armah, 1969, p. 63)
}

If Baako's African name sounds "unusual” to Brempong, then it gives an indication the kind of African Brempong is. Baako's African name sounds "unusual" to Brempong because the latter is the product of a colonized mentality, which teaches one to look down on one's own heritage and cultural identity and to elevate other hegemonic cultures and traditions above one's own. Brempong's unconscious subliminal response and attitude demonstrates what Frantz Fanon describes in Black Skin, White Masks as an "inferiority complex" that is very typical of colonized and mis-educated black men. It is a psychological complex, Fanon argues, which is perpetuated because the colonized black man "lives in a society that makes his inferiority complex 
possible" and "in a society that... proclaims the superiority of one race" (Fanon, 1986, p. 100). In such a society, an African bearing a simple culturally interpretable and decipherable name such as "Onipa" is considered peculiar, whereas another African bearing potentially verbose-to-the-African-ear European names such as "Henry Robert Hudson" - Brempong's self-acclaimed Christian names - is considered normal. ${ }^{3}$

Baako informs Brempong that he is not a Christian, implying that this is why he does not have a Christian name. At play here is Baako's self-awareness and state of consciousness vis-àvis the neo-colonial mindset of Brempong, who seems oblivious of the fact that his view that Baako's name is "unusual" (Armah, 1969 , p. 4) is rather an indictment of him. ${ }^{4}$ Baako is a proud and conscious African in contrast to Brempong, characterised as neo-colonially minded and thoroughly materialistic:

There are important things you can't get to buy at home. Every time I go out I arrange to buy all I need, suits and so on. It's quite simple. I got two good cars on this trip. German cars, right from the factory, all fresh. They're following me. Shipped. (Armah, 1969, p. 65)

Brempong, as Ode Ogede argues, is "[r]uled by his belief that his country is inferior to Europe," and for this reason has to ensure that "every time he goes abroad he buys all he needs"

3 Baako's name "Onipa" means "human being" or "person" in the Akan language of Ghana, thus making it clearly and identifiably African. To the contrary it would be extremely difficult for an African to interpret "Henry Robert Hudson." What do these mean in the African context? The name "Baako" also means and signifies "one," "single," or "alone" in Akan. Onipa Baako then is a self-consciously authored name to indicate the alienation, solitude and loneliness that Baako feels throughout in his interaction with his family and the wider Ghanaian community.

4 Brempong's name Henry Robert Hudson Brempong initialized as HRH is also within the novel's anti-colonially structured narrative framework a satirical ideological take on both European and African royalty; H R H in this respect standing for and being a play on the European titular His Royal Highness or Her Royal Highness. It is also significant that the $17^{\text {th }}$ century English navigator and explorer, Henry Hudson, who was literally at the leading edge of the English colonial enterprise in North America lends his name to Brempong, who is definitely no navigator or explorer on behalf of the emergent nation of Ghana. Furthermore, the word "Brempong" derives from "Obrempong," which in the Ghanaian Akan language means "Royal."

Legon Journal of the Humanities 31.1 (2020)

\begin{tabular}{l|l} 
Page & 97
\end{tabular} 
(Ogede, 2000, p. 61). Brempong further represents the middle class Africans who Frantz Fanon describes in his chapter, "The Pitfalls of National Consciousness" in The Wretched of the Earth as "not engaged in production, nor in invention" and who are "completely canalized into activities of the intermediary type" (Fanon, 1967, p. 120). Fragments presents educated middleclass Ghanaians like Brempong as not interested in changing the destiny of their under-developed and neo-colonially structured nation; they are not like Baako, who at least is interested in being creative. Instead, their "innermost vocation seems to be to keep in the running and to be part of the racket" (Fanon, 1967, p. 120).

\section{Neo-colonialist materialism and consumerism} versus creative patriotism and nationalism

Unlike Baako, who is concerned with deploying his intellectual capabilities in contributing to the material and spiritual development of his nation, Brempong, trapped within a materially acquisitive culture sees the West merely as a reference point and source for obtaining all the good things in life:

"You see this." Brempong had brought out his lighter. "Where in Ghana would you find a thing like this? Sharp eyes. I bought it in Amsterdam, at the airport. Beautiful things there, Amsterdam. Tape recorders. I took one last year, and it has never given me any trouble." He leaned back completely, and his voice relaxed to a quiet sound just above a whisper. "You just have to know what to look for when you get a chance to go abroad. Otherwise you come back empty-handed like a fool, and all the time you spent is a waste, useless." A loud, forced guffaw broke the easy tenor of his voice. "But if you come back prepared, there's nothing to worry about." (Armah, 1969, p. 66) 
Especially with Africa's neo-colonial history, one would expect the likes of Brempong, returnees and been-to's from abroad with a wealth of experience in how other more technologically and industrially advanced and materially productive societies have worked, to come home with knowledge to help transform their nations. Instead, the Brempong's of an apparently decolonized and post-independent Ghana and Africa are trapped within an acquisitive - as against a creative - culture in relation to Western goods and products. Brempong's fascination with European goods and creature comforts represents an excessive penchant for the conspicuous consumption of goods from abroad that with careful and proper visionary planning could be produced at home too. Fragments consequently establishes a very interesting angle to the discussion of neo-colonial unconsciousness. Put another way, Armah demonstrates how the ideological Western supra-state apparatus dominates multiple spheres of life within the neo-colony thereby reducing the productive capacity of the people into consumerist appendages of a global market. Under this system, Brempong sees materialist consumption as equivalent to productive capacity. Rather ironically, the creative and progressively-minded Baako is the one who is considered in Brempong's deeply materialistic terms "a fool"; it is also Baako who paradoxically is considered by Brempong and society as "a waste" and "useless" (Armah, 1969, p. 66). Baako's character is very largely at odds with the perception of him as "a big man," an identity that his family and society construct and impose on him, but to which he personally does not subscribe. "It's no use", Brempong informs Baako, "going back with nothing ... and those at home must benefit too. I don't see the sense in returning with nothing" (Armah, 1969, p. 76).

The views expressed here by Brempong are distorted and represent a particularly short-sighted approach to existence within post-independent Ghana. For, unlike Baako, Brempong has absolutely no sense of commitment to ensuring that his own society is also able to be productive so that people like 
himself can also be innovative producers rather than simply passive consumers. The characterization of Brempong proves, as Joyce Johnson has argued, that Armah "contrasts the people's idea of their needs, material goods brought back" from Europe, "with their real need, which is to develop their own potential for progress" (Colmer, 1992, p. 211). Brempong's attitude is presented and projected as typically representative of the views of unconscious individuals; and for the class of people like him, as Rosemary Colmer further argues, "[t]heir materialistic vision has resulted in a loss of connection with the spiritual world which can only be deleterious to those modern Ghanaians who are losing their way and misdirecting their journey" (Colmer, 1992, p. 193). It is within this general sense that Fragments indicates how the culture of materialism associated with individuals like Brempong is communally pervasive. For example, when Baako's mother first encounters the Puerto Rican Juana, who will later become Baako's friend at the beach, Efua says of his son: "he went away to study. He will come back a man. A big man" (Armah, 1969, p. 50). Within the context of the novel's depiction of big-manism, Baako is expected to be like Brempong. Consequently, upon their arrival in Ghana, Brempong's sister scrutinising Baako at the airport is confounded by the latter's simple and unassuming appearance and questions: "You mean he is also a been-to"?

\section{Elitism, bigmanism and nation-building}

Baako's lack of a big man status does not merely make him a "fool" and "useless," in the eyes of materialistically-minded members of society; it has wider ramifications for members of his family. Consequently, for example, at the crucial moment in the novel when his sister Araba is in labour and has to be rushed to the nation's main hospital, Baako, Araba and the taxi driver who drives them to the hospital are treated very disrespectfully by a nurse on duty for the simple reason that Baako does not project the big-man clout and power status to influence the 
direction of events and ensure that Araba is taken to one of the better delivery wards. The following exchange between Baako, the nurse and the taxi driver, who takes the hapless Baako and the labouring Araba to the hospital is illustrative:

"This is the new maternity ward," the driver said when he came to a stop in front of a tall new concrete and glass structure. He called out to a passing nurse, "Awuraa nurse," and the nurse came closer squinting with ill humour, "there's a baby being born in the car."

"Are you the father?" the nurse asked, looking at Baako

"No." He pointed to Araba in the back. "She's my sister." "Are you a Senior Officer?"

"Look, I'm not in the Civil Service yet."

"Well," the nurse could hardly contain her disdain, "is the real husband a Senior Officer?"

"No," Baako said. "But why are you asking?"

"Look, beautiful awuraa Nurse," the driver said, winking broadly at the girl, "the woman is suffering." "Taxi driver" The nurse made the words come out like shots. "I am not speaking to you." The driver looked away and whistled the refrain of the last high life song he had been singing. "So what is your status" she asked, turning to Baako again.

"I have no status," he said. He saw the nurse's brows rise and the corners of her lips fall.

"Well," she said. "This new wing is for VIP's and Senior Officers. The rest to the old wards."

And where are the old wards?"

"There" the nurse pointed with perfunctory disdain and swung off into the interior of the modern building. (Armah, 1969, pp. 106 - 107; emphasis added) 
The Ghanaian society of Fragments is characterized by elitism and big-manism. It is possible to see the "modern building" itself as representative of the new modern nation-state of Ghana that is being built on parts of the old colonial foundation and one might even assume that all Ghanaians are to enter this structure; however, the taxi driver, Araba, who is pregnant with new life and Baako her "been-to" brother are members of the society who cannot find a space within significant parts of the nation, which are reserved only for a certain class of people. Even such a potentially dangerous situation as suffering the pangs of child-birth does not bother the nurse at all in any way because all the people that she is associating with in the exchanges above are beneath a certain status within society, leading her to treat them with what the narrative describes as total "disdain."

Even more significant, however, in relation to the incident that we witness above, is that when they are turned away Araba's "look of panic" is replaced by "a flat, hurt look" (Armah, 1969, p. 108) and her disappointment as she silently mouths the words "been-to" is largely because Baako is unable to use that status to help her in her moment of need. As Baako himself soon discovers, Brempong is paradoxically right when he says: "You have to know people. Big people not useless people. Top officials who can go anywhere and say, 'Do this, do that, for my boy!" (Armah, 1969, p. 68). Baako will soon realize to his chagrin that not knowing big people within the Ghanaian system is a huge disadvantage, a point to which we shall return soon below.

The elitism and deep class structure of the society is subtended by a serious neo-colonial attitude that is pervasive within the entire country and exists at all levels of society. What is significant about this situation is that the educated elite of the country are very much aware of the absurdities of the inequalities within the Ghanaian system. At the airport, the person meeting Brempong on his arrival is delayed, and when Brempong inquires why, the following conversation takes place: 
"Ah, there you are, Mensah," Brempong said when he saw him. "They sent you to meet me?"

"Yes sir, "the young man said. There were beads of perspiration on his nose. 'I'm sorry I'm late, but the police guard wouldn't let me in."

"Why didn't you show him your papers? Didn't they give you any?

"He was an escort, sir. He asked if I was coming like this to meet a white man. I said no, a Ghanaian. He curled his top lip and just stopped me."

"These escorts are idiots. You should have told him you were meeting a white man."

\section{"I was thinking of that. But a General Police sergeant came and when I showed him the papers he told the escort they were for a very big man. So, I came immediately." \\ Brempong chuckled and looked at his wife. \\ "The fools" the woman said. (Armah, 1969, pp. 79- 80; emphasis added)}

Further evident here is the fact that the consciousness of certain Ghanaians is shaped by a sinister neo-colonial attitude, in which they look down upon and disregard and disrespect fellow Ghanaians. Thus, aside the specific issue of acquisitive materialism previously described and elaborated - as indicated in the character and behaviour of the likes of Brempong - the community generally suffers the malaise of neo-colonialism. Already seen in the servile attitude of Brempong towards European goods, it is repeated here in the unpleasant behaviour of the policeman, who would have given the person welcoming Brempong respectful treatment if he were "a white man." The policeman only relents and allows Brempong's escort to proceed because the latter is going to meet "a very big man." This crassly 
crude neo-colonial mentality and an attitude of big-manism is also on display in a different sense at the ceremony that welcomes Brempong home from England and which Baako witnesses as further testimony to how members of the community are alienated from themselves:

A strange scene greeted him as he strode into the arrivals lounge. Three tough-looking men in white jumpers with their cloths balled around their waists were holding Brempong high above their heads. Around them a large crowd of the hero's relatives struggled to get closer to him, shouting, some singing in an ecstatic, emotional confusion.

"Eieeei! Our white man, we saw you wave! We saw you!"

"The big man has come again"

"Oh, they have made you a white man."

"Complete!"

"And you have come back to us, your own. Thank God." "Yes, praise him!! (Armah, 1969, pp. 80 - 81; emphasis added)

Brempong's elite status combines the worst forms of European and African power. On display in the apparently independent nation is a servile attitude to Europeaness. Thus, the neo-colonial consciousness and culture of materialism evident in the behaviour of Brempong is not only attributable to some of Ghana's newly-educated elites; even low down the social ladder ordinary members of Brempong's family and the community at large are trapped within a debilitating cycle of inferiority where white men are seen as superior beings. The description of Brempong as "our white man" is an expression that demonstrates a common proclivity for worshipping people and things foreign. Particularly striking and significant here is the fact that Brempong does not reject the reference to him as 
"a white man," but revels and indulges in it thus revealing how much of a mimic man he is. Ode Ogede argues that:

some Africans, like Robert Hudson Brempong, strive to look like whites... and dress and speak like whites. This mimicry manifests the Africans' acceptance of the false notions of European superiority... For Armah, the matter of grave concern is the way these elites reinforced roles of colonial apemanship, slavish imitativeness, and sham man (Ogede, 2000, pp. 60-61)

The adulation for Brempong that is on exhibition at the airport is not simply because he is in the eyes of his community a "big man" who has returned happily to jubilant acclaim, but also because of his ostentatious character. When champagne is poured at his feet in the joyous ritual of welcome and celebration and "[a] lone voice gasped audibly, in spite of the spirit of the moment, that this was a lot of drink to waste this way," Brempong retorts: "Oh don't worry" (Armah, 1969, p. 83).

\section{Communally pervasive neo-colonialism}

It is instructive to point out though that Armah's critique in Fragments is not only directed at the culture of neo-colonialism. Brempong's name translated into the Akan language of the Ghanaian people means "royal." Consequently, being borne skyhigh at the airport could also be read symbolically as the ride in the palanquin that is part of a Ghanaian chief's ceremonial itinerary of adulation and respect and a simultaneous critique of the authority and veneration associated with it..$^{5}$ Indeed, the narrative establishes some form of ideological congruence between Brempong's role as a chief in a palanquin and the possibilities of power - both real and illusionary:

5 It should be noted here that Chieftaincy in and of itself is not necessarily inherently a problematic institution; the suggestion here, however, is that Brempong's enjoyment of the kingly status and hero-worship accorded him is also an instance of personal aggrandizement.

Legon Journal of the Humanities 31.1 (2020)

Page $\mid 105$ 
It was not a mere game. Not to the welcomers he had seen this night. More insistently, Baako saw the ceremony working itself out: the straining crowd, the clothes, the jewels, the cascading drink, the worship of this new chief, the care, the words in the night. Did it matter whether there was real power or real joy as long as the human beings involved thought there was? So what if these words and ceremonies were the mere outward show of power and joy hiding impotence? Who was going to stand outside it all and say maybe the show was designed to hide impotence, but all it did was steep this powerlessness in a worsening stupidity. (Armah, 1969, p. 89)

The "impotence" referred to in the passage above is Armah's self-conscious way of demonstrating the hollow vacuity of a majority of the Ghanaian elite. The display and show of power is in the end futile if not completely superfluous and meaningless to a people, who really require developing their nation instead of celebrating heroic individuals, who have nothing concrete and substantial to offer their society aside a materialistic culture. Relevant here is the role that the individual plays in relation to the community and what the real benefits to be derived from that relationship thereof are.

The narrative takes a clear stance on this issue when Baako observes that "there was no question of his joining Brempong's happy world" and that there is a "clear wall between him and Brempong” (Armah, 1969, p. 89). Baako totally rejects participating in the neo-colonial culture, seeing himself as a deeply conscious person and as an African engaged in resisting all efforts at colonial indoctrination and mimicry. He says as much to his mother when he is asked to be Master of Ceremonies at the outdooring ceremony of his sister Araba's child, a role that he takes on somewhat reluctantly as seen in the 
following conversation between himself and his mother Efua:

"Anyway," she said, "you know you're the M.C. today."

"Yes. What do I have to do?"

"I am not the one who has been abroad to a university," his mother said, smiling full into his face.

"What I went to learn was different," he said.

"Well, there won't be too much to do. I wish you had brought a tux, or at least a suit, though. It would have been so fine."

"I'm not an ape."

"What a strange thing to say!" his mother said.

"Why else would I wear tuxes and suits in this warm country except to play monkey to the white man?" "But for a sacred ceremony like this..."

"I suppose your sacred ancestors laid down the word that we should sweat in stupid suits and tuxes for such ceremonies." Too bad. I'm going to wear clothes that won't choke me."

"Oh Baako," his mother said, with real hurt in her voice, "I was only thinking of the best. Baako what happened to you?"

"What do you mean?" (Armah, 1969, p.)

In this exchange Baako is expressing his displeasure at the colonial mind-set and behaviour of his people. Baako's apprehensions and his strong aversion to colonial culture are totally lost on his mother Efua who is apparently and in her own mind only "thinking of the best." Baako's "alienation" argues $\mathrm{V}$ Nirmala, "is not only from the society but also from his family because of the family's inability to understand that his ambitions are not primarily material ones" (Nirmala, 2008, pp. 60-61). Efua's misperception that aping the white men is the better culture for her son and her community is a general ideological 
posture that persists within the community as a whole. Baako's reference of his mother to the community's "sacred ancestors," who have "laid down the word" - a reference to the type of cultural attitudes, beliefs and philosophies articulated by a previous generation - is meant to draw her attention to this fact. Baako is representative in this sense, in Joyce Johnson's terms, of "the situation of the Western-educated African who is attempting to re-establish links with his traditional cultural background or to identify with ordinary people" (Johnson, 1992, p. 205). Armah himself, very much aware of the process of alienation and displacement undergone by Western-educated African intellectuals has argued elsewhere that:

Leaving home to go to school, within the colonial context, invariably meant moving away from such home realities, to enter a formally organized world of temporal power in which African realities were actively minimized or negated, while the official dogma of Europe as the exclusive source of significant value was triumphantly projected. (Armah, 2006, pp. 9-10)

It is within this context that Baako's mother Efua is presented in Fragments as seemingly highly incognizant of the loss of important communal values such as the belief in one's own cultural institutions and the need to dress and live in tune with one's own environment. Instead Baako, the returning traveller from abroad and the member of the community who has a properly integrated sense of self in relation to these issues, and who is moreover conscious in this regard of the significant cultural losses incurred by the broader African historical self, is the one who appears to members of his family, community and nation as an oddity. The misperception of Baako as "strange," which triggers his mother Efua's question about what happened to him - "Baako what happened to you?" - a question posed 
with a great measure of certainty and confidence is testimony to the actual loss of an African sense of self by Baako's family and the wider Ghanaian community.

The sense of estrangement from family and wider community engendered within Baako comes simultaneously with a consciousness of knowing exactly who he is. Presented as very familiar with African history and aware of the direction that his thinking and his life should take, he cannot be said in the sense in which Robert Fraser suggests, to be aware that he is a "deficient been-to" (Fraser, 1980, p. 33). ${ }^{6}$ Baako seeks personal and communal self-rehabilitation. It is highly significant in this regard that Baako's anti neo-colonial posture is juxtaposed to the portrait of the crowd in attendance during the outdooring ceremony of Araba's child. The Ghanaian attendees at the outdooring who form the crowd are presented in their physical outlook as totally alienated from themselves and their environment:

There was a rich crowd of guests, too, sitting at first like a picture already taken. Woollen suits, flashing shoes, important crossed legs, bright rings showing on intertwined fingers held in front of restful bellies, an authentic cold-climate overcoat from Europe or America held traveller-fashion over an arm, five or six waistcoats, silken ties and silver clasps, and a magnificent sane man in a university gown reigning over four admiring women in white lace covershirts on new dumas cloth; long, twinkling earrings, gold necklaces, quick-shining wristwatches, a great rich splendour stifling all these people in the warmth of a beautiful day (Armah, 1969, p. 259; emphasis

6 Robert Fraser argues that: "Baako realizes that he is sadly a deficient "been to," for he brings home "neither limousine nor deep-freeze: nothing in fact save a guitar and typewriter and a mere devotion to his lone but ardent craft of writing" (Fraser, 1980: 33). It is not really the case that Bako can be considered or accepts to be a "deficient" been to. To the contrary, he realizes his value and the potential he has to contribute efficiently to the development of his nation. He is stifled, however, by the neo-colonialist Ghanaian power elite and clique. 
added)

It is within this suffocating social atmosphere that Baako's relationship and conversations with Juana, the Puerto Rican doctor who has migrated to Ghana become relevant. Juana is herself fleeing certain forms of alienation in her society. In conversation with Baako, he informs Juana about "the fear of the return" and "the society he had come back to and the many ways in which it made him feel his aloneness" (Armah, 1969, p. 145):

She asked him about his family, thinking of some possible shelter, but when he spoke of it, his family became only a closer, intenser, more intimate reflection of the society itself, a concave mirror, as he called it (Armah, 1969, pp. 145 - 146)

Armah's critique of the causes of alienation in Fragments extends to the heart of the nation and to the heart of power or indeed to the powerful characters who are called big men. The moment in the narrative when Baako having been so very frustrated in his attempts to get a job at Ghanavision is forced to seek help is demonstrative. Together with his old school teacher Ocran, whom he visits and who he tells his predicament, they visit the Principal Secretary, a big man in a position to help ensure that Baako's application is more expeditiously processed:

The Principal Secretary sucked his teeth loudly and asked Ocran if he'd like something to drink. Ocran shook his head, and when Baako did the same the Principal Secretary finished sucking his teeth and said in a flat tone of voice, "We don't have modern systems here. This country [Ghana] doesn't work that way. If you come back thinking you can make things work in any smooth, efficient way, you'll just get a complete waste of your time. It's not worth 
bothering about." Ocran let out a hot sigh but said nothing. The Principal Secretary drew his free hand across his glistening forehead and continued. "Unfortunately - he winked at Ocran - the young man will also be finding out that making a go of life means forgetting all the beautiful stuff they teach in the classroom. It's very different. The way things really work. (Armah, 1969, p. 118).

Prior to visiting Principal Ocran and accompanying Baako to see the Principal Secretary Ocran had informed Baako that: "If you want to do any real work here, you have to decide quite soon that you'll work alone" (Armah, 1969, p. 115). His fears are confirmed by the Principal Secretary's shocking comments in the passage above. Fanon argues in his chapter on "The Pitfalls of National Consciousness" that "in an underdeveloped country an authentic national middle class ought to consider it as its bounden duty to betray the calling that fate has marked out for it" (Fanon, 1967: 120). Fanon's argument can be taken to mean that the group seen as the educated elite should have the interest of their nation at heart. That is precisely the stance that Baako adopts. Baako wants, in Fanon's words, to put himself "to school with the people" and "to put at the people's disposal the intellectual and technical capital that it has snatched when going through the colonial universities" (Fanon, 1967, p. 120).

\section{Alienation vis-à-vis national consciousness}

While this is precisely the attitude that Baako - creative artist, filmmaker and visionary has - and which he wishes to dedicate to the service of his community and country, he encounters obstacles, here, there and everywhere. Being informed as he is by the Principal Secretary that Ghana "doesn't work" the "way" committed and dedicated servants, artistes and other 
professionally trained individuals like himself see it, is already enough to break any dedicated person's resolve. To refer once more to Fanon, the Principal Secretary's attitude can be said to "not follow [the] heroic, positive, fruitful and just path" (Fanon, 1967, p. 120) that Baako and Ocran represent within the novel's articulation of a properly defined national consciousness. The Principal Secretary's condoning attitude is illustrative of one whose "soul is set at peace into the shocking ways - shocking because anti-national" as Fanon aptly puts it, and which furthermore symbolizes the inanity of "a traditional bourgeoisie which is stupidly, contemptibly, cynically bourgeois" (Fanon, 1967, pp. 120-21). After the visit to the Principal Secretary's, Ocran drives: "like a drunken man, talking in his rage":

"You heard him. You're supposed to forget everything you've ever learned. It's all nothing to him, and to the others like him. You'll be agreeing with him all too soon. I hate these stupid Ghanaian big shots. They know things don't work, but they're happy to sit on top of the mess all the time. Now he feels he's done us a great favour, and that's the way he wants it. You're expected to be grateful. The machinery doesn't work, except as a special favour for special ones... They sit on their bottoms doing. (Armah,1969, p. 119; emphasis added)

The same anti-national neo-colonially unprogressive attitude persists when Baako finally gets the job at Ghanavision. ${ }^{7}$ In a meeting with the Head of the corporation, Baako encounters difficulty presenting his simple and direct vision on script:

7 V Nirmala contends that while Baako is "filled with idealism and enthusiasm," and "wants to contribute his creativity to his Ghanaian nation," it happens to be the case that "the new Ghana is so immersed in soul-deadening materialism and corruption that that it has little space for youthful idealists, let alone creative writers" like Baako (Nirmala, 2008: 59)

Legon Journal of the Humanities 31.1 (2020)

Page $\mid 112$ 
At the production meeting when he'd presented this treatment, Asante-Smith had stopped him just here and asked, "What is it about?"

"Slavery"

"Why such a choice of topic?"

"How do you mean, why?"

"You understand me, Mr Onipa," said Asante-Smith, with a small yawn. 'Look, we're a free, independent people. We're engaged in gigantic task of nation building. We have inherited a glorious culture, and that's what we're here to deal with."

"Slavery is a central part of that culture, isn't it?"

Around the table everyone was sitting very still and quiet.

"Do you have any others?"

"I'd like to finish this."

"Look, don't waste time. I have an appointment at twelve."

"There's another here, The Brand," Baako said.

"What's that about?"

"Survival."

"Mr Onipa," said Asante-Smith. "I know what the trouble is with you. You're too abstract in your approach to our work. For instance, what you've just said has nothing to do with our people's culture - all this slavery, survival, the brand."

"It has everything to do with it," Baako answered, surprised at the force of his own anger. (Armah, 1969, pp. 208 -209)

Baako is very critical of the "educated elite" (Armah, 1969, p. 210) like Asante-Smith, described earlier in the novel by Brempong as a sycophant who sings the praise of his masters. In his condemnation of Asante-Smith, Baako suggests that the latter is typically representative of " $[\mathrm{t}]$ he educated really 
thinking of the people here [in Ghana] as some kind of devils in a burning hell, and themselves the happy plucked ones, saved" (Armah,1969, p. 210). In short, a majority of the Ghanaian elite are an over-privileged lot, thoroughly and totally undeserving of their privileged status, especially to the extent that they remain a deeply unpatriotic and opportunistic group, simply riding on their elite status. ${ }^{8}$ Neil Lazarus makes the point very clearly when he argues that:

What is at issue in Asante-Smith's attitude is, for Armah, nothing less than the abdication of his responsibility as an intellectual. Having been educated at the expense of the community at large, Asante-Smith and the majority of other intellectuals portrayed in Fragments now expect to be rewarded simply for what they represent, as "been-to's," rather than for what they do as skilled members of society (Lazarus, 1990, p. 90).

The intellectual lethargy displayed by the likes of AsanteSmith is typical of an insolent and lazy Ghanaian middle class of whom Asante-Smith and the likes of the Principal Secretary are most aptly representative. Armah's "second and third novels, Fragments and Why Are We So Blest?," points out Rosemary Colmer, "are statements about the alienation of the educated elite from the people, and the sense of dissociation and personal dissolution which this induces in those of the elite who feel that their place is among the people" (Colmer, 1992, p. 191; emphasis added). What Fragments very clearly demonstrates in its depiction of post-independent Ghana is that Baako - writer, creative artist, visionary and would-be-revolutionary - certainly

8 Rao Damodar argues that:

"What he [Bako] finds at Ghanavision is total negation of purposeful thinking... Asante-Smith, the Director of Ghana Vision and his colleagues are incapable of anything that is creative and their commitment is to the powers-that-be...Bako's commitment to his society and his artistic vocation are out of tune with a people who are known for their creative impotence" (Rao, 1993: 67)

Legon Journal of the Humanities 31.1 (2020) 
feels this sense of "personal dissolution," loss and alienation. This is evident throughout the novel in his actions and in is his conversations with Ocran, Juana, his mother Efua and other members of the Ghanaian national community. 


\section{References}

Armah, A. K. (2006). The Eloquence of the Scribes: A memoir on the sources and resources of African literature. Popenguine, Per Ankh: The African Publishing Cooperative.

Colmer, R. (1992). "The human and the divine: Fragments and Why are we so Blest?" In Wright D (Ed.) Critical perspectives on Ayi Kwei Armah. Washington, D C: Three Continents Press, 191203.

Fanon, F. (1967). The Wretched of the Earth. London: Penguin Books.

Fraser, R. (1980). The novels of Ayi Kwei Armah. London: Heinemann.

Johnson, Joyce (1992). "The promethean 'factor' in Ayi Kwei Armah's Fragments and Why are we so Blest?" In Wright D (Ed.) Critical perspectives on Ayi Kwei Armah. Washington, D C: Three Continents Press, 204-216.

Lazarus, N. (1990). Resistance in postcolonial African fiction. New Haven and London: Yale University Press.

Nirmala, V. (2008) Armah's fiction: A study in decolonising cultural hegemony. New Delhi, Prestige.

Ogede, O. S. (2000) Ayi Kwei Armah: Radical iconoclast: Pitting imaginary words against the actual. Athens, Ohio University Press.

Petersen, K. H. (1992). "Loss and frustration: An analysis of A. K. Armah's Fragments.". In Wright D (Ed.) Critical perspectives on Ayi Kwei Armah. Washington, D C: Three Continents Press, 217 226.

Damodar, R. K. (1993) The novels of Ayi Kwei Armah. New Delhi: Mehra Offset Press.

Wright, D. (1989). Ayi Kwei Armah's Africa: The sources of his fiction. London, Hans Zell 